\title{
Reconstruction of Atlantic water variability during the Holocene in the western Barents Sea
}

\author{
D. E. Groot, S. Aagaard-Sørensen, and K. Husum \\ Department of Geology, University of Troms $\varnothing$, Troms $\varnothing$, Norway \\ Correspondence to: D. E. Groot (diane.e.groot@uit.no) \\ Received: 3 July 2013 - Published in Clim. Past Discuss.: 30 July 2013 \\ Revised: 26 November 2013 - Accepted: 29 November 2013 - Published: 10 January 2014
}

\begin{abstract}
The gravity core JM09-KA11-GC from 345 m water depth on the western Barents Sea margin was investigated for down-core distribution patterns of benthic Foraminifera, stable isotopes, and sedimentological parameters in order to reconstruct the flow of Atlantic water during the Holocene. The core site is located below the Atlantic water masses flowing into the Arctic Ocean and close to the Arctic front. The results show continuous presence of Atlantic water at the margin throughout the Holocene. During the early Holocene, (11 500-9800 cal yr BP), bottom water temperatures as calculated by transfer functions rose by $1.5^{\circ} \mathrm{C}$, likely due to the increased inflow of Atlantic water, although sea ice was still present at this time. The transition to the mid-Holocene is characterized by a local shift in current regime, resulting in a ceased supply of fine-grained material to the core location. Throughout the mid-Holocene the $\delta^{18} \mathrm{O}$ values indicate a slight cooling, thereby following changes in insolation. In the last $1500 \mathrm{yr}$, inflow of Atlantic water increased but was interrupted by periods of increased influence of Arctic water causing periodically colder and more unstable conditions.
\end{abstract}

\section{Introduction}

The climate in the European Arctic is strongly dependent on the inflow of warm and saline Atlantic water masses transported to the high northern latitudes by the North Atlantic Current (NAC). Its most distal branch, the West Spitsbergen Current (WSC), is considered to be the major pathway for heat, salt, and water flux to the Arctic Ocean (e.g., Aagaard and Greisman, 1975).

Throughout the Holocene, the strength of Atlantic water inflow into the northern North Atlantic has varied, al- though with smaller amplitude than recorded for the glacialinterglacial scale changes (e.g., Klitgaard-Kristensen et al., 2001; Risebrobakken et al., 2003; Hald et al., 2007). Several marine records in the Barents Sea region have demonstrated that these smaller variations in the intensity of Atlantic water inflow during the Holocene still have a strong impact on climate at the high northern latitudes (e.g., Duplessy et al., 2001; Lubinski et al., 2001; Sarnthein et al., 2003; Slubowska-Woldengen et al., 2007). These studies indicate that short- and long-term climatic changes, such as the transition from the warm early Holocene to the cool and stable mid-Holocene, are associated with changes in the flow of Atlantic water and the oceanic conveyor belt in addition to changes in insolation forcing. Furthermore, variability of Atlantic water inflow has been attributed to location and strength of westerly winds (e.g., Risebrobakken et al., 2010; Dylmer et al., 2013).

The purpose of the present study is to reconstruct the past variability of Atlantic water inflow at the western Barents Sea margin during the Holocene. We studied a sediment core retrieved from the relatively small Kveithola Trough located at the western Barents Sea margin. The trough has acted as a natural sediment trap and holds $130 \mathrm{~cm}$ of Holocene sediments, allowing for a sampling resolution at decadal to centennial timescales (Rüther et al., 2012). At present, the study area is dominated by Atlantic water masses (Berben et al., 2013) and is located close to the Arctic front. Therefore this site is suitable for examining past variability of Atlantic bottom water inflow at the western Barents Sea margin. We examined down-core distribution patterns of benthic foraminiferal faunas and benthic stable isotopes, and we quantitatively reconstructed bottom water temperatures and salinities using transfer functions. 
A)

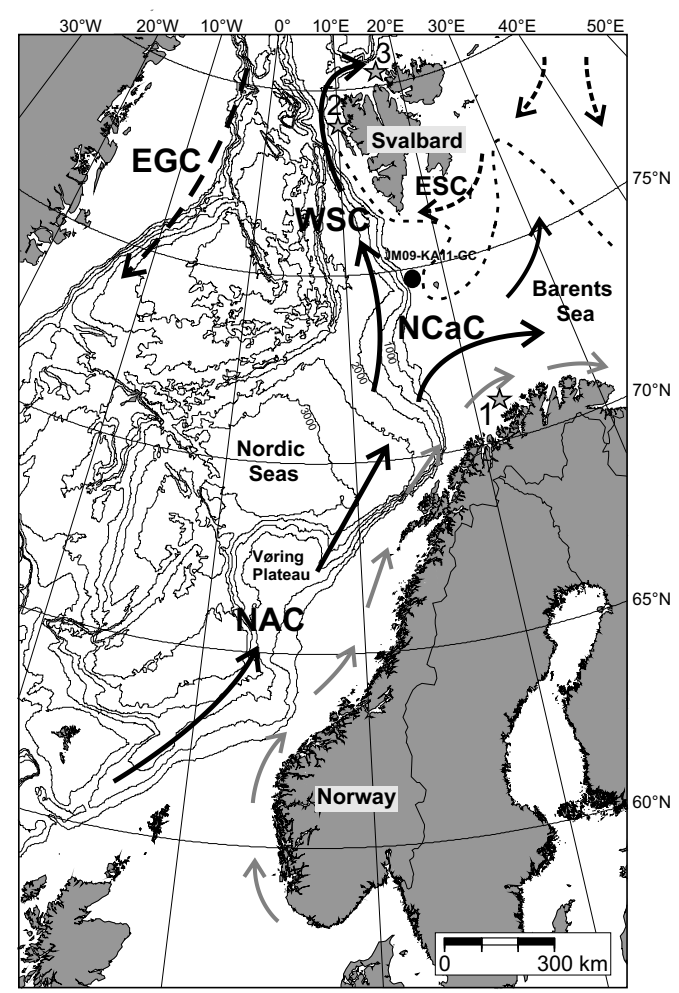

B)

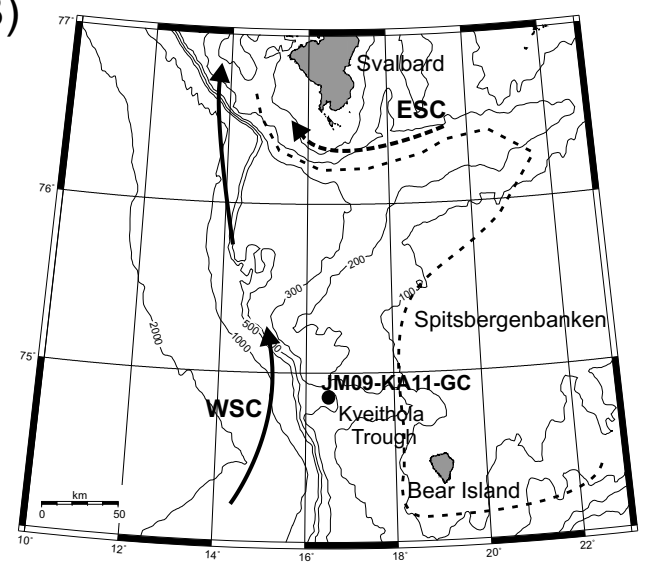

Fig. 1. (A) Location of core JM09-KA11-GC together with main surface current systems in the region. Dashed line indicates the present-day position of the Arctic front (after Loeng, 1991). Black currents indicate Atlantic water, grey currents coastal water, dashed black currents Arctic water. Abbreviations are NAC, North Atlantic Current; NCaC, North Cape Current; WSC, West Spitsbergen Current; ESC, East Spitsbergen Current; EGC, East Greenland Current. Numbers indicate cores used for comparison, 1: core PSh-5159N (Risebrobakken et al., 2010), 2: core NP05-11-21GC (Skirbekk et al., 2010), 3: core NP94-51 (Ślubowska et al., 2005). (B) Detailed map of study area showing location of studied core.

\section{Oceanographic setting}

Kveithola Trough is located at the western Barents Sea margin, to the NW of Bear Island (Fig. 1). It is a $100 \mathrm{~km}$ long east-west trending trough, $15-20 \mathrm{~km}$-wide with a water depth ranging from 200 to $400 \mathrm{~m}$ (Rüther et al., 2012).

At present, the Barents Sea is influenced by three main water masses: Atlantic water, Arctic water and coastal water. Warm and salty Atlantic water $\left(>3{ }^{\circ} \mathrm{C},>35.0 \mathrm{psu}\right.$; Loeng, 1991) is transported northwards by the NAC following the continental slope of Norway (Fig. 1a). The topographically steered flow of Atlantic water splits into two branches at ca. $72^{\circ} \mathrm{N}$. One branch flows into the southern Barents Sea as the North Cape Current (NCaC) (Loeng, 1991). The other branch continues northwards along the Barents Sea slope and western Svalbard margin into the Arctic Ocean as the WSC (Aagaard et al., 1987) (Fig. 1a). The Arctic water mass, formed by mixing of Atlantic water and polar water in the Arctic Ocean, enters the Barents Sea from the north and is carried southward by the East Spitsbergen Current (ESC) and around the Svalbard archipelago (Loeng, 1991). This water mass has a low salinity (34.3-34.8 psu) but is mostly charac- terized by temperatures $<0^{\circ} \mathrm{C}$ and the seasonal cover by sea ice (Loeng, 1991). Spitsbergenbanken, which encloses Kveithola Trough (Fig. 1b), is occupied by Arctic water masses (Loeng, 1991). Transport of cold and sediment-laden shelf bottom waters from Spitsbergenbanken through Kveithola Trough to the continental slope is reported by Fohrmann et al. (1998). The boundary between Arctic and Atlantic water is the Arctic front (also called the polar front), which forms sharp climatic gradients in terms of temperature, salinity, and sea-ice distribution (Hopkins, 1991). At present, the Arctic front is located east of our study area and south of Bear Island (Ingvaldsen, 2005). Generation of dense deep water by brine rejection primarily takes place at the Svalbard bank area and in the eastern Barents Sea (Midttun, 1985). Coastal water is present in the southern Barents Sea and is characterized by reduced salinities $\left(>2{ }^{\circ} \mathrm{C},<34.7 \mathrm{psu}\right.$; Loeng, 1991) due to freshwater runoff from the Norwegian mainland and from the Baltic Sea (Sætre, 2007). 


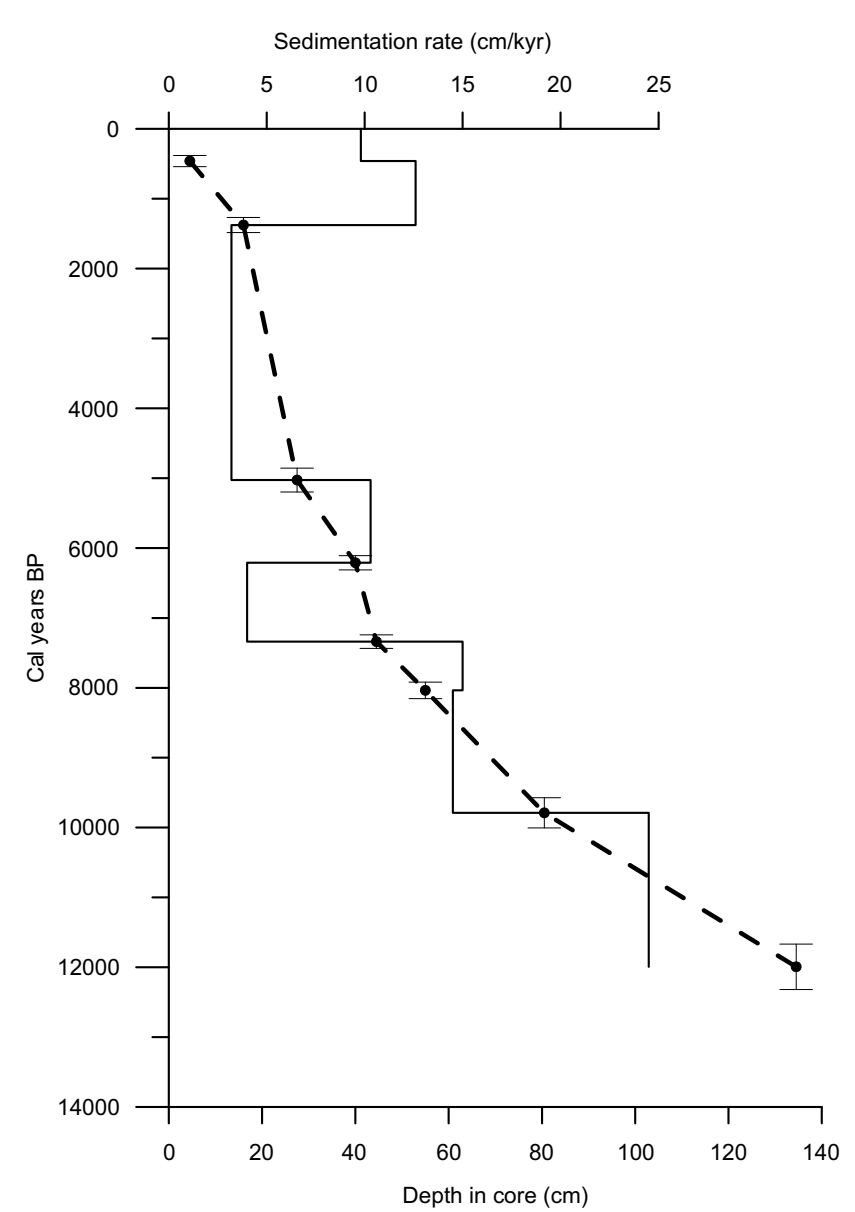

Fig. 2. Age model and sedimentation rate of JM09-KA11-GC. The $2 \sigma$ ranges are indicated on the dated levels. Chronology is established by linear interpolation between calibrated ages.

\section{Material and methods}

Gravity core JM09-KA11-GC (hereafter referred to as KA11) $\left(74^{\circ} 52.48^{\prime} \mathrm{N}, 16^{\circ} 29.08^{\prime} \mathrm{E}, 345 \mathrm{~m}\right.$ water depth) was obtained on a cruise of RV Jan Mayen in 2009 in the western part of the Kveithola Trough (Fig. 1). The lithology of KA11 was previously described by Rüther et al. (2012). The present study focuses on the upper $130 \mathrm{~cm}$ of the core.

The core was sampled continuously in $0.5 \mathrm{~cm}$-thick slices. All samples were weighed, freeze-dried, reweighed, and subsequently wet-sieved using mesh sizes of $63 \mu \mathrm{m}, 100 \mu \mathrm{m}$ and $1 \mathrm{~mm}$. After drying, the individual size fractions were weighed. At least 300 calcareous benthic Foraminifera from the $100 \mu \mathrm{m}$ to $1 \mathrm{~mm}$ size fraction were picked and identified to species level, following the guidelines from Knudsen (1998). All species from the Buccella genus were combined and referred to as Buccella spp. Furthermore, the morphologically similar species Islandiella helenae and Islandiella norcrossi were combined and referred to as $I s$ landiella spp. The relative abundance of the identified species was calculated in relation to all calcareous speci-

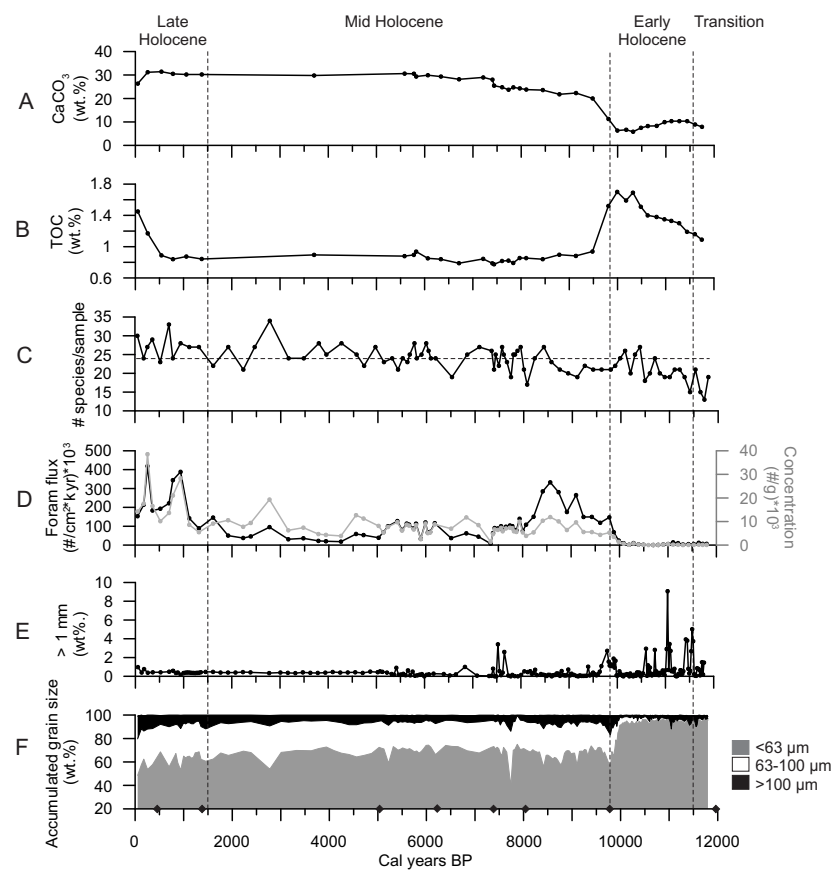

Fig. 3. Sediment properties of core JM09-KA11-GC. (A) $\mathrm{CaCO}_{3}$ as weight percentage. (B) TOC as weight percentage. (C) Number of benthic species per sample with dashed line indicating average value. (D) Benthic foraminiferal flux (left, black) together with foraminiferal concentration (right, grey). (E) Size fraction $>1 \mathrm{~mm}$ is considered as ice rafted debris (IRD). (F) Accumulated grain size as weight percentage. Black diamonds on $x$ axis indicate calibrated age points.

mens per sample. Agglutinated Foraminifera were nearly absent and therefore excluded from further analysis. The flux of calcareous benthic Foraminifera was calculated using the dry bulk density, sedimentation rate, and number of specimens per gram dry sediment as suggested by Ehrmann and Thiede (1985):

$$
\begin{aligned}
& \text { Flux }\left[\# \mathrm{~cm}^{-2} \times \mathrm{kyr}\right]=\left[\# \mathrm{~g}^{-1}\right] \times \text { dry bulk density }\left[\mathrm{g} \mathrm{cm}^{3}\right] \\
& \times \text { sedimentation rate }\left[\mathrm{cm} \mathrm{kyr}^{-1}\right],
\end{aligned}
$$

where \# is the number of benthic foraminiferal specimens.

Dry bulk density was calculated based on water content and wet bulk density and corrected for density of sea water.

Weight percentages of total carbon (TC), total organic carbon (TOC) and calcium carbonate $\left(\mathrm{CaCO}_{3}\right)$ were determined every ca. $4 \mathrm{~cm}$ on $1 \mathrm{~cm}$-thick sediment slices. TC and TOC were measured at the geological laboratory at the University of Troms $\varnothing$ using a LECO CS 2000 induction oven. The $\mathrm{CaCO}_{3}$ content was calculated using the equation $\mathrm{CaCO}_{3}=($ TC-TOC $) \times 100 / 12$.

Stable isotopes were measured at the Geological Mass Spectrometer (GMS) laboratory at the University of Bergen using a Finnigan 253 mass spectrometer, which has a reproducibility of $\pm 0.06 \%$ ofor $\delta^{18} \mathrm{O}$ equilibrium calcite $\left(\delta^{18} \mathrm{O}_{\mathrm{c}}\right)$. Stable isotope analyses were performed on the infaunal 
Table 1. AMS ${ }^{14} \mathrm{C}$ dates and calibrated dates for core JM09-KA11-GC. The dates were dated at TRa: Radiocarbon Laboratory in Trondheim, Norway, and Uppsala, Sweden, and Beta: Beta Analytic Inc. in Miami, Florida, US. Radiocarbon ages are calibrated in the Calib 7.0 program (Stuiver et al., 2005) using the Marine13 calibration curve (Reimer et al., 2013). A standard reservoir correction of $400 \mathrm{yr}$ and regional $\Delta \mathrm{R}$ value of $67 \pm 34$ (Mangerud and Gulliksen, 1975) was used. Dates marked with * are from Rüther et al. (2012).

\begin{tabular}{|c|c|c|c|c|c|c|c|}
\hline $\begin{array}{l}\text { Lab } \\
\text { reference }\end{array}$ & $\begin{array}{r}\text { Core } \\
\text { level }(\mathrm{cm})\end{array}$ & $\begin{array}{l}\text { Dated } \\
\text { material }\end{array}$ & $\begin{array}{l}{ }^{14} \mathrm{C} \\
\text { date }\end{array}$ & $\begin{array}{r}\text { Calibrated } \\
\text { age }\end{array}$ & $\begin{array}{r}\text { Calibrated } \\
\text { age range } \pm 2 \sigma\end{array}$ & $\begin{array}{r}\delta^{13} \mathrm{C} \\
(\% o)\end{array}$ & Comments \\
\hline TRa-1063 & $3-6$ & Bathyarca glacialis-unpaired & $925 \pm 30 *$ & 476 & $397-555$ & 2.3 & \\
\hline TRa-1064 & $3-6$ & Bathyarca glacialis-unpaired & $900 \pm 35^{*}$ & 445 & $354-535335-346$ & 4.5 & \\
\hline TRa-1065 & $15-17$ & Bathyarca glacialis & $1880 \pm 35^{*}$ & 1377 & $1268-1485$ & 4.4 & \\
\hline Beta-324049 & $27.5-28$ & Islandiella norcorssi/helenae & $4820 \pm 30$ & 5027 & $4856-5197$ & -1.5 & \\
\hline TRa-1066 & $32.5-33.5$ & Astarte elliptica-unpaired & $1990 \pm 35^{*}$ & 1469 & $1347-1590$ & 5.5 & not used \\
\hline Beta-315192 & $39.5-40.5$ & Islandiella norcorssi/helenae & $5870 \pm 30$ & 6211 & $6108-6313$ & -1.3 & \\
\hline Beta-315193 & $44-45$ & Islandiella norcorssi/helenae & $6890 \pm 40$ & 7339 & $7241-7436$ & -1.9 & \\
\hline TRa-1067 & $53-57$ & Astarte sulcata-unpaired & $7630 \pm 45^{*}$ & 8037 & $7919-8154$ & 5.7 & \\
\hline Beta-315194 & $80-81$ & Islandiella norcorssi/helenae & $9140 \pm 40$ & 9790 & $9573-10006$ & -2.6 & \\
\hline TRa-1068 & $81-83.5$ & Astarte elliptica-paired & $8140 \pm 50^{*}$ & 8541 & 8387-8695 & 3.6 & not used \\
\hline TRa-1069 & $81-83.5$ & Nuculana minuta-unpaired & $8315 \pm 50^{*}$ & 8783 & 8597-8968 & 4.7 & not used \\
\hline Beta-315195 & $110.5-111.5$ & Elphidium excavatum f. clavata & $10900 \pm 50$ & 12309 & $12130-12546$ & -2.8 & not used \\
\hline TRa-1070 & $133-136$ & Yoldiella intermedia-paired & $10705 \pm 55^{*}$ & 11993 & $11668-12318$ & 3.3 & \\
\hline
\end{tabular}

species Cassidulina neoteretis. The $\delta^{18} \mathrm{O}_{\mathrm{c}}$ values were corrected for disequilibrium with seawater by $+0.02 \%$ (Poole, 1994) and corrected for the ice-volume effect, where a sea-level change of $10 \mathrm{~m}$ corresponds to a $0.11 \%$ isotopic change (Fairbanks, 1989). All results are reported in \%o Vienna Pee Dee Belemnite (V-PDB).

Thirteen radiocarbon dates were obtained using accelerator mass spectrometry (Table 1); eight dates were previously published (Rüther et al., 2012). The radiocarbon dates were measured on mollusks and monospecific samples of benthic Foraminifera (Table 1). Dates from samples TRa-1066, TRa1068, and TRa-1069 were excluded from the age model as they were obtained on infaunal mollusk species, which might have migrated down in the sediment (E. Thomsen, personal communication, 27 February 2013; Mangerud et al., 2006). Further, sample Beta-315195 was excluded due to age reversal, possibly due to reworking. The radiocarbon dates were calibrated into calendar ages using Calib version 7.0 (Stuiver et al., 2005) and the marine calibration curve Marine13 (Reimer et al., 2013) with a local marine reservoir correction $(\Delta R)$ set as $67 \pm 34$ (Mangerud and Gulliksen, 1975). The age model is based on linear interpolation between the remaining nine dates. The means of the $2 \sigma$ age ranges are used as tie points in the interpolation (Fig. 2). All ages in this paper are given as calibrated years BP (present $=1950 \mathrm{AD})$.

Bottom water temperatures $\left(\mathrm{BWT}_{\mathrm{TF}}\right)$ and salinities $\left(\mathrm{BWS}_{\mathrm{TF}}\right)$ were reconstructed by transfer functions using the Sejrup et al. (2004) database of modern benthic Foraminifera. In this database Elphidium excavatum f. clavata and Elphidium excavatum f. selseyensis are combined although they represent different temperature regimes (i.e., arctic and boreal environment; Feyling-Hanssen, 1972). In core KA11 only E. excavatum f. clavata was identified.
Therefore the southernmost samples (Skagerrak, Kattegat and the Norwegian continental margin), which include $E$. excavatum f. selseyensis, were omitted. Additionally, three samples from fjords in Iceland were omitted since they represented a different environmental setting. Finally, Islandiella helenae and Islandiella norcrossi were combined in the database as well as the Buccella species. We used the C2 program (Juggings, 2010) and a weighted average partial least squares (WA-PLS) model for estimating temperature and salinity (ter Braak and Juggins, 1993). A fourcomponent WA-PLS model was used for temperature and a five-component WA-PLS model for salinity (Table 2). This selection was based on a low root mean square error (RMSE), the correlation between observed and estimated values $\left(r^{2}\right)$, and a low maximum bias (e.g., Birks, 1995) (Table 2).

\section{Results}

\subsection{Sedimentological parameters}

The highest sedimentation rates $\left(24.5 \mathrm{~cm} \mathrm{kyr}^{-1}\right)$ are observed between 11800 and $11500 \mathrm{yr}$ BP (Fig. 2). Throughout the Holocene, the sedimentation rates are much lower (3-12 $\mathrm{cm} \mathrm{kyr}^{-1}$ ) and generally decrease towards the present. Only during the last $1500 \mathrm{yr}$ the rates increase slightly to ca. $10 \mathrm{~cm} \mathrm{kyr}^{-1}$.

The sediments consist mainly of clay and silt. Between 11800 to $10000 \mathrm{yr}$ BP, the fraction $<63 \mu \mathrm{m}$ comprises more than $90 \%$ of the sediment, and some IRD clasts $>1 \mathrm{~mm}$ are observed (Fig. 3). At $10000 \mathrm{yr}$ BP the sand content increases and is relatively stable until $1000 \mathrm{yr}$ BP before slightly increasing again during the last $1000 \mathrm{yr}$. 
Table 2. Performance of transfer function model WA-PLS with components 1 to 5. Italics indicate performance of the selected models.

\begin{tabular}{lrrrrrrrr}
\hline Model & \multicolumn{3}{c}{ Temperature } & & \multicolumn{3}{c}{ Salinity } \\
\cline { 2 - 5 } \cline { 8 - 9 } & RMSE & $r^{2}$ & Max bias & & \multirow{2}{*}{ RMSE } & $r^{2}$ & Max bias \\
\hline WA-PLS component 1 & 1.24877 & 0.748377 & 2.34502 & & 0.106815 & 0.561906 & 0.573909 \\
WA-PLS component 2 & 1.12137 & 0.797089 & 1.72035 & & 0.0978157 & 0.632613 & 0.472159 \\
WA-PLS component 3 & 1.03408 & 0.827448 & 1.27498 & & 0.0923698 & 0.672383 & 0.399328 \\
WA-PLS component 4 & 0.996462 & 0.839779 & 1.0828 & & 0.0894319 & 0.692892 & 0.407719 \\
WA-PLS component 5 & 0.973128 & 0.847195 & 1.14311 & & 0.0858414 & & 0.717062 & 0.395228 \\
\hline
\end{tabular}

The TOC percentage declines significantly from 1.7 to $0.9 \mathrm{wt} \%$ at ca. $9800 \mathrm{yr} \mathrm{BP}$ and remains low, only to rise again in the last $600 \mathrm{yr}$ (Fig. 3). $\mathrm{CaCO}_{3}$ percentages show a slight decrease from ca. 11000 to $9800 \mathrm{yr} \mathrm{BP}$, and then rise rapidly from 6 to $20 \mathrm{wt} \%$, followed by a gradual increase from 20 to $30 \mathrm{wt} \%$ towards the present.

\subsection{Distribution of benthic Foraminifera}

The benthic foraminiferal assemblage is studied every 0.5 to $2.5 \mathrm{~cm}$ giving an average time resolution of $143 \mathrm{yr}$. A total of 54 species are identified. The number of species increases from 11800 to $10000 \mathrm{yr}$ BP from ca. 15 to $20-25$ species per sample and remains relatively stable at 25-30 species per sample throughout the remainder of the Holocene (Fig. 3). Most specimens have well-preserved tests, and no signs of dissolution are observed. Almost exclusively calcareous species are found, and the most frequent $(>5 \%$ abundance) are shown in Fig. 4. The total flux of benthic Foraminifera generally increases throughout the Holocene, with highest values observed between 9800 and $8000 \mathrm{yr}$ BP and during the last $1500 \mathrm{yr}$ (Fig. 3).

Three species dominate the benthic foraminiferal faunas: E. excavatum f. clavata, Cassidulina reniforme, and C. neoteretis (Fig. 4). Less frequently observed species are Stainforthia loeblichi, Nonionellina labradorica, Islandiella spp., Melonis barleeanus, Lobatula lobatula, and Astrononion gallowayi. From 11800 to $11500 \mathrm{yr}$ BP, S. loeblichi and $C$. reniforme dominate the fauna with mean values of 20 and $40 \%$ respectively. Countering the rapid decline of these two species, E. excavatum f. clavata increases till $11000 \mathrm{yr}$ BP and becomes the most abundant species with a mean value of $30 \%$. From 11500 to $9800 \mathrm{yr}$ BP, C. reniforme increases again to $40 \%$ abundance, and $C$. neoteretis increases from 6 to $30 \%$ abundance. During this period, N. labradorica and Islandiella spp. reach peak values of 25 and $14 \%$ at 10600 and $10500 \mathrm{yr} \mathrm{BP}$, respectively. In this same time interval, $A$. gallowayi increases to ca. $5 \%$ abundance at $10000 \mathrm{yr} \mathrm{BP}$, and M. barleeanus increases to ca. $10 \%$ at $10200 \mathrm{yr}$ BP. Both are otherwise present throughout the entire Holocene with average values of ca. 5 and $3 \%$ respectively. From $9800 \mathrm{yr}$ $\mathrm{BP}$ to present, the benthic foraminiferal assemblage is characterized by the dominance of $C$. neoteretis and C. reni- forme, which have mean values of 27 and $34 \%$ respectively. Some small changes are observed in the last $2000 \mathrm{yr}$ when the abundance and flux of E. excavatum f. clavata increases again, and in the last $1000 \mathrm{yr}$ M. barleeanus increases from 2 to $6 \%$ (Fig. 4 ).

\subsection{Stable isotopes}

Stable isotopes are analyzed on a higher time resolution than the benthic foraminiferal assemblages, giving an average resolution of $82 \mathrm{yr}$. The $\delta^{18} \mathrm{O}_{c}$ values are low (ca. 3.1\%o) at $11800 \mathrm{yr}$ BP and increase rapidly to ca. $3.4 \%$ at $11500 \mathrm{yr}$ BP (Fig. 5). From 11500 to $10400 \mathrm{yr} \mathrm{BP}$, the $\delta^{18} \mathrm{O}_{\mathrm{c}}$ values are stable at $3.4 \%$. The $\delta^{18} \mathrm{O}_{\mathrm{c}}$ values fluctuate between 10400 and $9500 \mathrm{yr}$ BP, after which they show a relatively stable, slightly increasing trend, with an average value of $3.7 \%$ throughout the rest of the Holocene.

\subsection{Bottom water temperatures and salinities}

Bottom water temperatures estimated by transfer functions increase from 0.7 to $3.2^{\circ} \mathrm{C}$ between 11800 and $10000 \mathrm{yr} \mathrm{BP}$ (Fig. 5). This increase, however, is punctuated by a brief cold interval with temperatures less than $1^{\circ} \mathrm{C}$ at ca. $10500 \mathrm{yr} \mathrm{BP}$. The last $10000 \mathrm{yr}$ show relatively stable temperatures with an average value of $3.2^{\circ} \mathrm{C} \pm 0.4$. The reconstructed salinity values exhibit a similar trend as the bottom water temperatures (Fig. 5) and increase from 34.7 to 34.9 psu between 11800 and $10000 \mathrm{yr}$ BP. After $10000 \mathrm{yr}$ BP the salinity is stable at $34.9 \mathrm{psu} \pm 0.03$. Although the present-day values are slightly higher that the reconstructed salinity and temperature values, they fall within the error bars of the transfer functions (Fig. 5).

\section{Paleo-oceanographic development at the western Barents Sea margin and regional correlation}

We divide our Holocene record into four time slices: Younger Dryas-Holocene transition (11 800-11 500 yr BP), early Holocene (11 500-9800 yr BP), mid-Holocene (9800$1500 \mathrm{yr} \mathrm{BP})$, and late Holocene (1500 yr BP-present). These subdivisions are based on changes in the benthic 


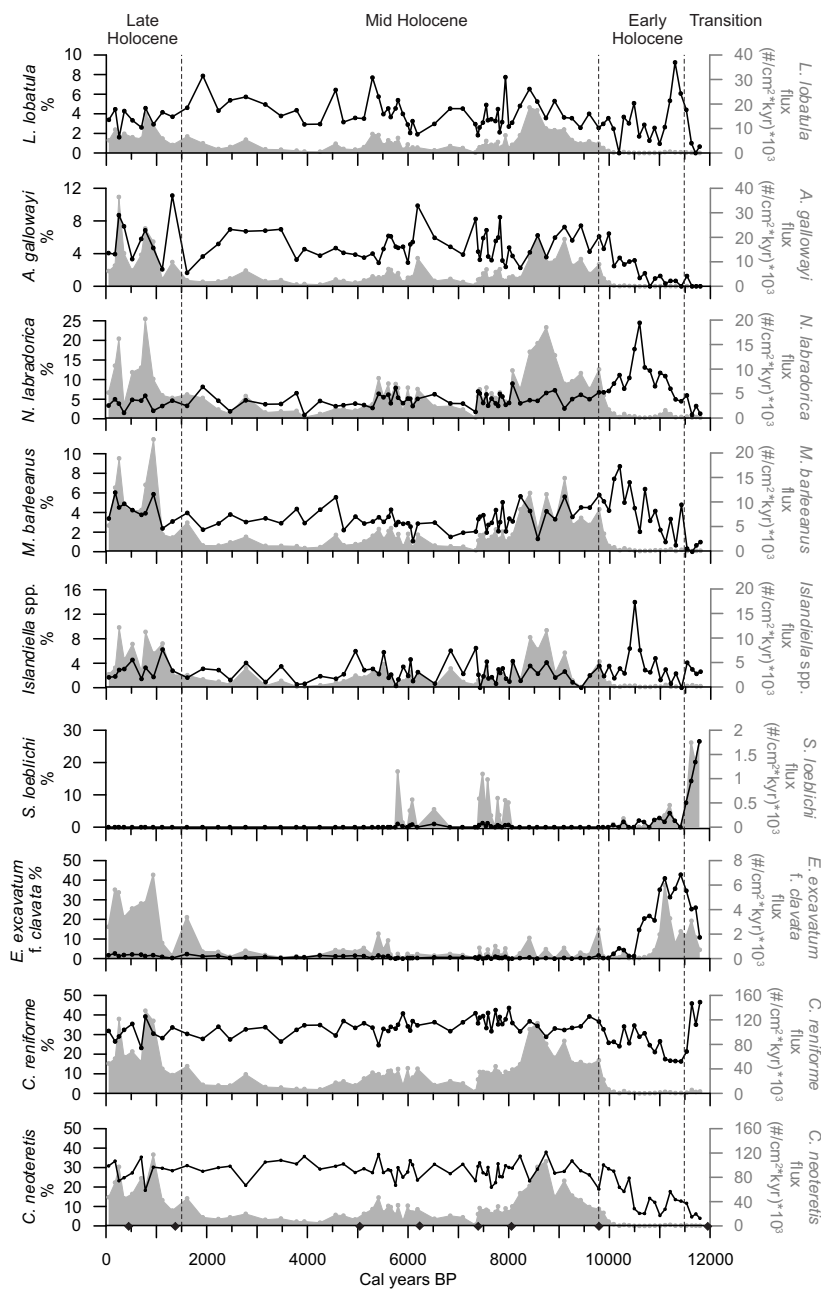

Fig. 4. Relative abundances (left, black) and fluxes (right, grey shading) of the most frequent benthic foraminiferal species versus calendar age BP. Note the different scales. Black diamonds on $x$ axis indicate calibrated age points.

foraminiferal fauna, stable oxygen isotopes, and grain-size distribution. Boundaries are placed at midpoints of changes.

\subsection{Younger Dryas-Holocene transition (11 800-11 500 yr BP)}

During the transition period from the Younger Dryas to the Holocene, the total benthic foraminiferal flux is low (Fig. 3), indicating unfavorable environmental conditions at the study site. This could be caused by the relatively high sedimentation rates and enhanced IRD production (Figs. 2, 3), which reflects increased sediment transport by icebergs and/or sea ice. Concordantly, depleted $\delta^{18} \mathrm{O}_{\mathrm{c}}$ values and the relatively low $\mathrm{BWS}_{\mathrm{TF}}$ values (Fig. 5) suggest a freshwater input. Unfavorable environmental conditions are further supported by the rapid increase of the opportunistic species E. excavatum f. clavata, which replaces $S$. loeblichi, a species associated

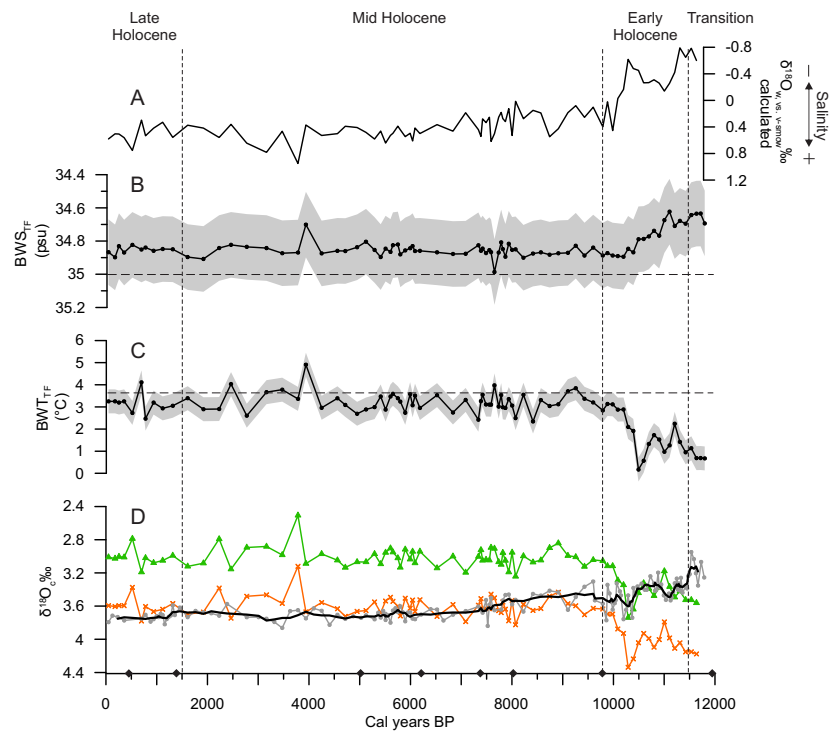

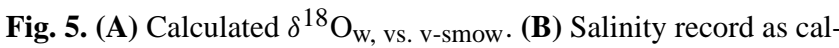
culated by transfer functions (black) with error bar in grey shading. Present-day salinity is indicated by dashed line. (C) Temperature record as calculated by transfer functions with error bar in grey shading. Present-day temperature is indicated by dashed line. (D) $\delta^{18} \mathrm{O}_{\mathrm{c}}$ record (grey line) with five-point running average (black line) together with calculated $\delta^{18} \mathrm{O}_{\mathrm{c}}$ from Kangerdlugssuaq Fjord (green, triangles) and Nordic Seas (orange, asterisks) mixing lines. Black diamonds on $x$ axis indicate calibrated age points.

with seasonal sea ice and pulses of seasonal high productivity (Steinsund, 1994; Polyak et al., 2002), and the glaciomarine indicator $C$. reniforme (e.g., Polyak et al., 2002) (Fig. 4). The presence of $E$. excavatum $\mathrm{f}$. clavata most likely reflects an environment with more extensive sea-ice cover, high turbidity, and lowered fluctuating salinities (Steinsund, 1994; Hald et al., 1994; Hald and Korsun, 1997). We therefore infer that the benthic foraminiferal assemblage reflects predominantly polar conditions with associated meltwater input. Rüther et al. (2012) report that since the deglaciation of Kveithola Trough (14200 yr BP) a semi-perennial sea-ice cover persisted. The timing of the deglaciation of the surrounding Spitsbergenbanken is not well constrained, but a minimum deglaciation age of $11200 \mathrm{yr}$ BP has been inferred for Bear Island (Wohlfarth et al., 1995). Meltwater from the glaciers located at Bear Island during the Younger Dryas would have been partly discharged through Kveithola Trough since its inner basin is connected to channels that drain parts of the Bear Island banks (Fohrmann et al., 1998). While the trough was still influenced by meltwater input and presence of sea ice, $\mathrm{BWT}_{\mathrm{TF}}$ started to rise (Fig. 5c), indicating an enhanced advection of Atlantic water to the western Barents Sea margin. This development corresponds to a regional pattern in the Barents Sea area with warm Atlantic water influencing the bottom waters at the end of the Younger Dryas (Rasmussen 
et al., 2007, 2012; Aagaard-Sørensen et al., 2010; Skirbekk et al., 2010).

\subsection{Early Holocene (11 500-9800 yr BP)}

During the early Holocene significant changes occurred in the foraminiferal fauna, which was still scarce but became more diverse (Fig. 3). Initially, the benthic assemblage was characterized by a polar fauna consisting of E. excavatum f. clavata and $C$. reniforme, indicating cold conditions with lowered salinities and possibly high water turbidity (Hald et al., 1994; Steinsund, 1994; Hald and Korsun, 1997). The decrease of E. excavatum f. clavata around $11000 \mathrm{yr} \mathrm{BP}$ and the coeval increase in $\mathrm{BWT}_{\mathrm{TF}}$ and $\mathrm{BWS}_{\mathrm{TF}}$ (Figs. 3, 5) suggest an overall improvement of environmental conditions reflecting the continued increasing inflow of Atlantic water. This is further corroborated by the increase of the subpolar species $C$. neoteretis, which is associated with chilled Atlantic water in the Arctic region (Mackensen and Hald, 1988; Steinsund, 1994; Seidenkrantz, 1995), and M. barleeanus, an arctic-boreal species that prefers higher salinities (Hald and Steinsund, 1992; Jennings et al., 2004) and is associated with the presence of Atlantic-derived waters in the Arctic (Polyak et al., 2002). The increase of M. barleeanus is concurrent with the increasing TOC content within sediments with continued high percentage of fine-grained material (Fig. 3). M. barleeanus is reported to feed on organic detritus, which can be delivered with fine sediments from shallow areas and then deposited in local depocenters (Polyak et al., 2002). Furthermore, the increase of $N$. labradorica from 11500 to $10600 \mathrm{yr}$ BP also supports an increased inflow of Atlantic water since this species is linked to the higher nutrient content of Atlantic-derived waters and oceanic fronts (Hald and Korsun, 1997; Rytter et al., 2002; Jennings et al., 2004; Lloyd, 2006). The pulse of Islandiella spp. shortly after the increase of $N$. labradorica points to a seasonal seaice cover and/or close proximity to the sea-ice margin (Hald and Steinsund, 1996). The presence of periodic sea-ice cover is further supported by a biomarker analysis on core KA11 (Berben et al., 2013), and by the low total flux (Fig. 3), indicating unfavorable conditions at the sea floor. A submerged inflow of Atlantic water beneath the sea ice would develop a stratified water column, which tends to limit biological productivity (Stein and Macdonald, 2004). The pulses of $N$. labradorica and Islandiella spp. indicate unstable environmental conditions and the presence of sea ice/proximity of the Arctic front at the western Barents Sea margin at $74^{\circ} \mathrm{N}$.

During the early Holocene, the overall increase of $\mathrm{BWT}_{\mathrm{TF}}$ (Fig. 5c) is concurrent with the enhanced inflow of Atlantic water. However, the temperature increase of the bottom waters can also be a response to reduced atmospheric heat exchange due to insulation by the sea-ice cover (Gerdes et al., 2003) that was present at this time (Berben et al., 2013). Hereby the excess heat would be stored in the water column and cause the $\mathrm{BWT}_{\mathrm{TF}}$ to increase. A similar response to insu- lation was observed in the SW Barents Sea (Risebrobakken et al., 2010).

The increasing $\delta^{18} \mathrm{O}_{\mathrm{c}}$ values seem to contradict the $\mathrm{BWT}_{\mathrm{T}}$ increase. These two opposing trends could imply that the $\delta^{18} \mathrm{O}_{\mathrm{c}}$ values are influenced by salinity changes. To determine the potential salinity-driven impact on the $\delta^{18} \mathrm{O}_{c}$ values, we calculated $\delta^{18} \mathrm{O}$ of water $\left(\delta^{18} \mathrm{O}_{\mathrm{w}, \mathrm{vs} . \mathrm{v} \text {-smow }}\right)$ (Fig. 5a) using the following temperature equation by Shackleton (1974):

$T\left({ }^{\circ} \mathrm{C}\right)=16.9-4 *\left(\delta^{18} \mathrm{O}_{\mathrm{c}}-\delta^{18} \mathrm{O}_{\mathrm{w}}\right)$,

whereby BWT $\mathrm{BW}_{\mathrm{TF}}$ is used as temperature input. $\delta^{18} \mathrm{O}_{\mathrm{w}}(\mathrm{PDB})$ was converted to SMOW scale by adding $+0.2 \%$ (Simstich

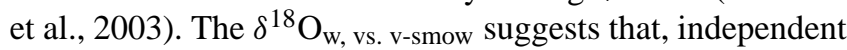
of which mixing line we use, the salinity increase over the early Holocene is underestimated in $\mathrm{BWS}_{\mathrm{TF}}$. The $\mathrm{BWS}_{\mathrm{TF}}$ suggests an increase of $0.2 \mathrm{psu}$, whereas $\delta^{18} \mathrm{O}_{\mathrm{w}}$, vs. v-smow suggests an increase of ca. 1 psu. Therefore, we propose that the $\mathrm{BWS}_{\mathrm{TF}}$ is likely underestimated, and salinity changes could have influenced the $\delta^{18} \mathrm{O}_{\mathrm{c}}$ values in the early Holocene.

A brief cold interval between 10700 and $10400 \mathrm{yr}$ BP interrupts the increase in $\mathrm{BWT}_{\mathrm{TF}}$. During this interval the temperatures decline by more than $1.5^{\circ} \mathrm{C}$ (Fig. $5 \mathrm{c}$ ) and seem to contradict the steady increase of Atlantic-water-associated species from ca. $11000 \mathrm{yr}$ BP towards the present, which does not indicate a temperature decline. When we compare the low $\mathrm{BWT}_{\mathrm{TF}}$ with the foraminiferal abundance, we find that the coldest points correlate with the highest abundances of N. labradorica and Islandiella spp. (Fig. 4). Both of these species are associated with high-productivity environments (Hald and Steinsund, 1996; Polyak et al., 2002), and $N$. labradorica is controlled more by food supply than by water temperature (Hald and Korsun, 1997; Lloyd, 2006; Ivanova et al., 2008). Further, the $\delta^{18} \mathrm{O}_{\mathrm{c}}$ values during the cold interval only show an increase of $0.15 \%$ (Fig. 5), whereas a temperature change of $1.5^{\circ} \mathrm{C}$ would correspond to an increase in $\delta^{18} \mathrm{O}_{\mathrm{c}}$ of $0.4 \%$ (Eq. 2). The offset between the $\delta^{18} \mathrm{O}_{\mathrm{c}}$ values and the $\mathrm{BWT}_{\mathrm{TF}}$ could be due to the different seasonal signal that these records represent. The transfer functions reflect average summer temperature (July, August, September; Sejrup et al., 2004), whereas the $\delta^{18} \mathrm{O}_{\mathrm{c}}$ value measured on $C$. neoteretis might reflect a different season. Hald et al. (2011) for instance report that for Malangen fjord C. neoteretis may calcify in late autumn. However, seasonal variability is expected to have only a minor effect on water masses at $345 \mathrm{~m}$ water depth. We therefore suggest that the brief temperature decline as reconstructed by transfer functions is likely overestimated due to the training set.

An increased inflow of Atlantic water in the early Holocene is also evident from several records from the Svalbard and Barents Sea region (e.g., Duplessy et al., 2005; Ślubowska-Woldengen et al., 2007; Chistyakova et al., 2010; Rasmussen et al., 2012; Klitgaard-Kristensen et al., 2013) and is associated with peak Holocene temperatures as observed by benthic oxygen isotopes in the SW Barents 


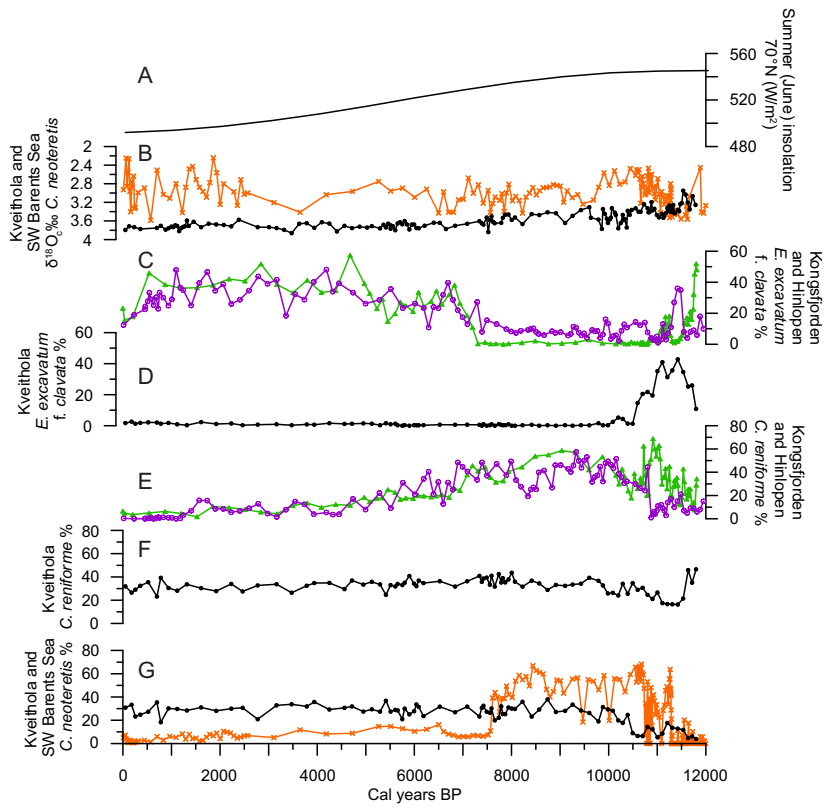

Fig. 6. Comparison of Holocene paleo-oceanographic development between Kveithola Trough, the SW Barents Sea (core PSh5159N) (Risebrobakken et al., 2010), Kongsfjorden (core NP0511-21GC) (Skirbekk et al., 2010) and Hinlopen Strait (core NP9451) (Ślubowska et al., 2005). For location of the selected cores see Fig. 1a. (A) June insolation at $70^{\circ} \mathrm{N}$ (Berger and Loutre, 1991). (B) ${ }^{18} \mathrm{O}_{\mathrm{c}}$ records from $C$. neoteretis for Kveithola (black, solid circles) and the SW Barents Sea (orange, asterisks). (C) Percentages of E. excavatum f. clavata for Kongsfjorden (green, triangles) and Hinlopen (purple, open circles). (D) Percentages of E. excavatum f. clavata for Kveithola (black, solid circles). (E) Percentages of $C$. reniforme for Kongsfjorden (green, triangles) and Hinlopen (purple, open circles). (F) Percentages of C. reniforme for Kveithola (black, solid circles). (G) Percentages of $C$. neoteretis for Kveithola (black, solid circles) and the SW Barents Sea (orange, asterisks).

Sea (Risebrobakken et al., 2010), transfer-function-generated bottom water temperatures (Rasmussen et al., 2013), and benthic foraminiferal assemblages (Ślubowska et al., 2005; Skirbekk et al., 2010) at the western and northern Svalbard shelf. Timing of the onset of increased inflow of Atlantic water agrees well between the SW Barents Sea, Kveithola, and the western Svalbard margin with an onset around $11500 \mathrm{yr}$ BP (Fig. 6). The northern Svalbard margin seems to be slightly delayed with a reported age of $10900 \mathrm{yr} \mathrm{BP}$ (Fig. 6) (Ślubowska et al., 2005). The increased inflow of Atlantic water in Kveithola Trough, however, did not result in peak Holocene temperatures. Neither the $\delta^{18} \mathrm{O}_{\mathrm{c}}$ values nor the benthic foraminiferal assemblages indicate warmer conditions in the early Holocene compared to the rest of our record (Figs. 4, 5). The early Holocene climate optimum is widely recognized in marine and terrestrial records from the Nordic Seas region. It is considered a response to the early Holocene orbital forcing (Renssen et al., 2009), resulting in higher-than-present summer insolation in the Northern
Hemisphere (Berger and Loutre, 1991) (Fig. 6), and as response to a stronger inflow of Atlantic water and the resulting intensified heat advection northward (Hald et al., 2007; Risebrobakken et al., 2011). The lack of the early Holocene warming optimum in the bottom waters of Kveithola Trough is consistent with a study by Risebrobakken et al. (2011). They show that ocean temperatures underneath the summer mixed layer in the eastern Nordic Seas do not increase significantly at this time and must instead be representative of the mean state of Atlantic water inflow. Additionally, at the time of maximum heat transport through the NAC (around 10000 yr BP; Risebrobakken et al., 2011), our study site was still influenced by Arctic water (Berben et al., 2013), thereby possibly suppressing the warming signal.

The end of the early Holocene is marked by a rapid decrease of TOC content at $9800 \mathrm{yr}$ BP, corresponding with changes observed in sedimentation rate and grain size. We speculate that these changes most likely represent a regime change of the current system whereby the supply of finegrained sediments and organic material through winnowing of the shallow bank areas enclosing Kveithola Trough ceased. Winnowing is not an uncommon feature in the early Holocene in the region, although in the southern Barents Sea it ceased ca. $1000 \mathrm{yr}$ later at $8700 \mathrm{yr}$ BP due to eustatic sealevel rise (Hald and Vorren, 1984). The ceased winnowing of the shallow banks enclosing Kveithola Trough might be explained by a lowered influence of Arctic water masses occupying Spitsbergenbanken to the $\mathrm{N}$ and NE of Kveithola. This is supported by Berben et al. (2013), who report that the (sub-)surface waters were dominated by Arctic water until ca. $9800 \mathrm{yr}$ BP, after which the marginal ice zone retreated.

To illustrate the transition from the early to the midHolocene further, Eq. 2 is used to calculate $\delta^{18} \mathrm{O}_{\text {c }}$, whereby temperatures are based on $\mathrm{BWT}_{\mathrm{TF}}$, and $\delta^{18} \mathrm{O}_{\mathrm{w}}(\mathrm{PDB})$ was calculated from $\mathrm{BWS}_{\mathrm{TF}}$ by applying two different mixing lines (Fig. 5d). For the early Holocene a mixing line from Kangerdlugssuaq Fjord, eastern Greenland (AzetsuScott and Tan, 1997), representing an oceanographic setting with cooled Atlantic water beneath a cold surface water layer, agrees best with the measured $\delta^{18} \mathrm{O}_{\mathrm{c}}$. The mid- and lateHolocene-measured $\delta^{18} \mathrm{O}_{\mathrm{c}}$ agrees best with a mixing line for the Nordic Seas (Simstich et al., 2003). The clear correlation of the measured $\delta^{18} \mathrm{O}_{\mathrm{c}}$ with two distinctively different mixing lines for the early and mid-Holocene illustrates the shift in oceanographic regime at the western Barents Sea margin to less glaciomarine conditions.

\subsection{Mid-Holocene (9800-1500 yr BP)}

The mid-Holocene is characterized by a stable benthic faunal distribution that is dominated by two species: $C$. neoteretis and $C$. reniforme. Together they comprise more than $60 \%$ of the fauna. This indicates a consistent inflow of Atlantic water throughout the mid-Holocene that had increased compared to the early Holocene. Further, the stable values of $\mathrm{CaCO}_{3}$ 
content (wt.\%) and the increased total benthic foraminiferal flux (Fig. 3) imply a more productive, stable environment due to the constant inflow of Atlantic water.

Throughout the mid-Holocene, $\delta^{18} \mathrm{O}_{\mathrm{c}}$ values are increasing by $0.35 \%$. This implies either a temperature decrease of $>1.5^{\circ} \mathrm{C}$, a salinity increase of 1 psu (Eq. 2), or a combination of these. However, neither a change in $\mathrm{BWT}_{\mathrm{TF}}, \mathrm{BWS}_{\mathrm{TF}}$ nor $\delta^{18} \mathrm{O}_{\mathrm{w}}$ is observed. This indicates there is an offset between the temperature trend as recorded by $\delta^{18} \mathrm{O}_{\mathrm{c}}$ values and the $\mathrm{BWT}_{\mathrm{TF}}$. The offset might be explained by the temperature change taking place over a long period of time $(8000 \mathrm{yr})$ and the temperature change being too small to affect the benthic foraminiferal assemblage. The dominant species $C$. neoteretis, for instance, is observed in temperatures ranging from $0{ }^{\circ} \mathrm{C}$ to $4^{\circ} \mathrm{C}$ (Rytter et al., 2002). Furthermore, BWT $\mathrm{TF}$ and $\delta^{18} \mathrm{O}_{\mathrm{c}}$ do not vary on the same amplitude. Whereas temperatures in the $\mathrm{BWT}_{\mathrm{TF}}$ records vary by $2.5^{\circ} \mathrm{C}$, corresponding to a $\delta^{18} \mathrm{O}_{\mathrm{c}}$ of $0.7 \%$ (Eq. 2), the $\delta^{18} \mathrm{O}_{\mathrm{c}}$ record shows only minor variability $(0.3 \%$ ) . The amplitude difference between the measured $\delta^{18} \mathrm{O}_{\mathrm{c}}$ and reconstructed $\mathrm{BWT}_{\mathrm{TF}}$ indicates that a benthic foraminiferal fauna is not only affected by temperature and salinity but also nutrient availability exerts an influence via marked changes in the so-called "food indicator species" (e.g., N. labradorica, Islandiella spp., M. barleeanus; Hald and Korsun, 1997; Polyak et al., 2002; Lloyd, 2006; Ivanova et al., 2008). Thus, the large temperature variations in the $\mathrm{BWT}_{\mathrm{TF}}$ are most likely an overestimation due to the training set, and we must conclude that the training set and transfer functions used in the present study are not able to capture the small temperature variations as suggested by our $\delta^{18} \mathrm{O}_{\mathrm{c}}$ values.

Based on the increasing $\delta^{18} \mathrm{O}_{\mathrm{c}}$ values, the stable BWS and the offset of $\mathrm{BWT}_{\mathrm{TF}}$, we suggest that decreasing temperatures are the most plausible explanation for the $\delta^{18} \mathrm{O}_{\mathrm{c}}$ trend. The temperature decline in Kveithola is hereby consistent with decreasing bottom water temperatures in the Barents Sea region as recorded by distribution patterns of benthic Foraminifera and benthic $\delta^{18} \mathrm{O}_{\mathrm{c}}$ values (e.g., Husum and Hald, 2004; Ślubowska-Woldengen et al., 2007; Risebrobakken et al., 2010; Rasmussen et al., 2012). The decreasing bottom water temperatures in the Barents Sea region seem to follow the insolation trend at $70^{\circ} \mathrm{N}$ (Fig. 6) (Berger and Loutre, 1991). However, recent studies from the Nordic Seas show that proxies beneath the summer mixed layer have a smaller response to the insolation than the surface waters (Andersson et al., 2010; Risebrobakken et al., 2011). The bottom waters in the Barents Sea region are therefore likely to reflect the general state of the NAC, which has cooled due to decreasing insolation in the Northern Hemisphere.

\subsection{Late Holocene (1500 yr BP-present)}

Throughout the last $1500 \mathrm{yr}$, more unstable conditions have been observed compared to the mid-Holocene. The coarse grain-size fraction has increased, episodes of enhanced pro- ductivity are suggested by peak values in foraminiferal flux, and small changes in the species composition and abundances occur (Figs. 3, 4). The coarser grain-size fraction suggests a more vigorous current regime, probably due to a stronger inflow of Atlantic water at the western Barents Sea margin. A regional increased inflow of Atlantic water is suggested by benthic foraminiferal and coccolith records, and a sortable silt record from the western and northern margins of the Barents Sea and Svalbard (Lubinski et al., 2001; Hass, 2002; Ślubowska et al., 2005; Jernas et al., 2013; Dylmer et al., 2013).

The episodes of enhanced productivity in Kveithola suggest a higher availability of nutrients. We observe an increase in the abundance of M. barleeanus, pointing to a change in food availability (Polyak et al., 2002), and an increase in TOC content. At the same time, a biomarker analysis on core KA11 shows that the study site is again influenced by seasonal sea ice in the late Holocene (Berben et al., 2013). The fluxes of E. excavatum f. clavata reach the same level as during the early Holocene (Fig. 3), although with a much lower relative abundance $(<5 \%)$. Apparently, conditions are becoming more favorable for this species, which could indicate periodically colder conditions or a higher turbidity of the water column (Steinsund, 1994; Hald et al., 1994; Hald and Korsun, 1997). However, colder conditions are not observed in the $\delta^{18} \mathrm{O}_{\mathrm{c}}$ values or in the $\mathrm{BWT}_{\mathrm{TF}}$ (Fig. 5). The changes that are observed in productivity, foraminiferal abundance, and sea-ice presence (Berben et al., 2013) might suggest that an oceanographic front, associated with sea ice and higher productivity, is moving towards our core location.

The unstable bottom water conditions as observed by the benthic foraminiferal fauna are also observed in several other benthic foraminiferal records in the Barents Sea and Svalbard region (Ślubowska et al., 2005; Ślubowska-Woldengen et al., 2007; Chistyakova et al., 2010; Risebrobakken et al., 2010; Rasmussen et al., 2012; Jernas et al., 2013), although timing of the onset differs between the regions (Fig. 6). In the SW Barents Sea and western Svalbard margin, bottom water conditions have become more unstable over the past two millennia (Chistyakova et al., 2010; Risebrobakken et al., 2010; Rasmussen et al., 2012; Jernas et al., 2013). ŚlubowskaWoldengen et al. (2007) report an onset of unstable conditions at the western Svalbard margin $1000 \mathrm{yr}$ ago, whereas at Kveithola we observe a shift in bottom water conditions $1500 \mathrm{yr}$ ago. These unstable conditions are attributed to a strengthened inflow of Atlantic water to the Arctic (Rasmussen et al., 2012; Jernas et al., 2013) and (periodically) colder conditions at the surface, which are linked to weaker southwesterlies (Risebrobakken et al., 2012) and decreasing insolation (Rasmussen et al., 2012; Berben et al., 2013). The differences in timing between the SW Barents Sea, Kveithola and the western Svalbard margin may represent a localized response to a regional trend or potential inconsistencies between the age models. 
With the stable temperature trend throughout the late Holocene, core KA11 differs from other records from the Barents Sea and western Svalbard margin that record temperature changes. Several studies record a cooling in the late Holocene in both the bottom (Ślubowska-Woldengen et al., 2007; Risebrobakken et al., 2010) and surface water masses (Voronina et al., 2001; Hald et al., 2007; Rasmussen et al., 2007; Risebrobakken et al., 2010), which could be related to declining summer insolation (Berger and Loutre, 1991) or displacements of Arctic and polar water masses (Hald et al., 2007). Opposite to this cooling, two high-resolution studies from Bear Island (Wilson et al., 2011) and the western and northern Svalbard shelf (Jernas et al., 2013) infer a warming over the last $\sim 200 \mathrm{yr}$ induced by the renewed inflow of Atlantic water. In Kveithola Trough we do not observe a temperature increase over the last few hundred years, which may be due to loss of the uppermost sediment during the coring procedure.

\section{Conclusions}

A sediment core from the western Barents Sea margin was analyzed with regard to benthic foraminiferal assemblages, stable isotopes, and sedimentological parameters in high resolution in order to elucidate past variability of Atlantic bottom water during the Holocene. Further, bottom water temperatures and salinities were reconstructed with transfer functions.

Our results show that Atlantic water has continuously been present at the western Barents Sea margin throughout the studied interval. The transition from the Younger Dryas to the Holocene occurred between 11800 and $11500 \mathrm{yr}$ BP and is characterized by glaciomarine conditions with extensive sea-ice cover and meltwater input as suggested by low $\delta^{18} \mathrm{O}_{\mathrm{c}}$ and salinity values. During the early Holocene the inflow of Atlantic water increased, although sea ice was still present in Kveithola Trough. Our BWT $\mathrm{TF}_{\mathrm{TF}}$ suggests a rapid warming whereby the predominantly polar benthic foraminiferal fauna was replaced by a subpolar fauna. The following transition to the mid-Holocene is characterized by a local shift in current regime through, which we speculate that the supply of fine material from the shallow bank areas surrounding Kveithola Trough ceased. The mid-Holocene (9800-1500 yr BP) was a stable climatic period with favorable environmental conditions, and throughout this time there was a consistent inflow of Atlantic water. Bottom water temperatures declined during the mid-Holocene, thereby following the insolation curve at $70^{\circ} \mathrm{N}$. During the last $1500 \mathrm{yr}$ the inflow of Atlantic water increased as observed from the coarser grain-size fraction. However, climatic conditions also became more unstable, which may be related to periods of increased influence of Arctic water that caused periodically colder conditions.
Acknowledgements. This work is a contribution to the CASE Initial Training Network funded by the European Community's 7th Framework Programme FP7 2007/2013, Marie-Curie Actions, under grant agreement no. 238111. Additional funding was provided by the Norwegian Research Council. We thank B. Risebrobakken, D. Rüther, K. Skirbekk, and M. Ślubowska-Woldengen for sharing their data. We also thank Edel Ellingsen for picking Foraminifera for AMS dates and Jan P. Holm for providing the maps for Fig. 1. The comments from two anonymous reviewers helped to improve the manuscript considerably.

Edited by: J. Giraudeau

\section{References}

Aagaard, K. and Greisman, P.: Toward New Mass and Heat Budgets for the Arctic Ocean, J. Geophys. Res., 80, 3821-3827, doi:10.1029/JC080i027p03821, 1975.

Aagaard, K., Foldvik, A., and Hillman, S. R.: The West Spitsbergen Current: Disposition and Water Mass Transformation, J. Geophys. Res., 92, 3778-3784, doi:10.1029/JC092iC04p03778, 1987.

Aagaard-Sørensen, S., Husum, K., Hald, M., and Knies, J.: Paleoceanographic development in the SW Barents Sea during the Late Weichselian-Early Holocene transition, Quaternary Sci. Rev., 29, 3442-3456, doi:10.1016/j.quascirev.2010.08.014, 2010.

Andersson, C., Pausata, F. S. R., Jansen, E., Risebrobakken, B., and Telford, R. J.: Holocene trends in the foraminifer record from the Norwegian Sea and the North Atlantic Ocean, Clim. Past, 6, 179-193, doi:10.5194/cp-6-179-2010, 2010.

Azetsu-Scott, K. and Tan, F.C.: Oxygen isotope studies from Iceland to an East Greenland Fjord: behavior of glacial meltwater plume, Mar. Chem., 56, 239-251, 1997.

Berben, S. M. P., Husum, K., Cabedo-Sanz, P., and Belt, S. T.: Holocene sub centennial evolution of Atlantic water inflow and sea ice distribution in the western Barents Sea, Clim. Past Discuss., 9, 4893-4938, doi:10.5194/cpd-9-4893-2013, 2013.

Berger, A. and Loutre, M.: Insolation values for the climate of the last 10 million years, Quaternary Sci. Rev., 10, 297-317, doi:10.1016/0277-3791(91)90033-Q, 1991.

Birks, H. J. B.: Quantitative paleoenvironmental reconstructions, in: Statistical modelling of Quaternary science data, edited by: Maddy, D. and Brew, J. S., Quaternary Research Association, Cambridge, UK, 116-254, 1995.

Chistyakova, N., Ivanova, E., Risebrobakken, B., Ovsepyan, E., and Ovsepyan, Y.: Reconstruction of the postglacial environments in the southwestern Barents Sea based on foraminiferal assemblages, Oceanology, 50, 573-581, doi:10.1134/S0001437010040132, 2010.

Duplessy, J. C., Ivanova, E., Murdmaa, I., Paterne, M., and Labeyrie, L.: Holocene paleoceanography of the northern Barents Sea and variations of the northward heat transport by the Atlantic Ocean, Boreas, 30, 2-16, doi:10.1111/j.15023885.2001.tb00984.x, 2001.

Duplessy, J. C., Cortijo, E., Ivanova, E., Khusid, T., Labeyrie, L., Levitan, M., Murdmaa, I., and Paterne, M.: Paleoceanography of the Barents Sea during the Holocene, Paleoceanography, 20, PA4004, doi:10.1029/2004PA001116, 2005. 
Dylmer, C. V., Giraudeau, J., Eynaud, F., Husum, K., and De Vernal, A.: Northward advection of Atlantic water in the eastern Nordic Seas over the last $3000 \mathrm{yr}$ : a coccolith investigation of volume transport and surface water changes, Clim. Past Discuss., 9, 1259-1295, doi:10.5194/cpd-9-1259-2013, 2013.

Ehrmann, W. U. and Thiede, J.: History of Mesozoic and Cenozoic sediment fluxes to the North Atlantic Ocean, Contributions to Sedimentology, 15, 1-109, 1985.

Fairbanks, R. G.: A 17,000-year glacio-eustatic sea level record: influence of glacial melting rates on the Younger Dryas event and deep-ocean circulation, Nature, 342, 637-642, 1989.

Feyling-Hanssen, R. W.: The Foraminifer Elphidium excavatum (Terquem) and Its Variant Forms, Micropaleontology, 18, 337354, 1972.

Fohrmann, H., Backhaus, J. O., Blaume, F., and Rumohr, J.: Sediments in bottom-arrested gravity plumes: numerical case studies, J. Phys. Oceanogr., 28, 2250-2274, 1998.

Gerdes, R., Karcher, M. J., Kauker, F., and Schauer, U.: Causes and development of repeated Arctic Ocean warming events, Geophys. Res. Lett., 30, 1980, doi:10.1029/2003GL018080, 2003.

Hald, M. and Korsun, S.: Distribution of modern benthic foraminifera from fjords of Svalbard, European Arctic, The J. Foraminif. Res., 27, 101-122, doi:10.2113/gsjfr.27.2.101, 1997.

Hald, M. and Steinsund, P. I.: Distribution of surface sediment benthic foraminifera in the southwestern Barents Sea, The J. Foraminif. Res., 22, 347-362, doi:10.2113/gsjfr.22.4.347, 1992.

Hald, M. and Steinsund, P. I.: Benthic foraminifera and carbonate dissolution in the surface sediments of the Barents and Kara Seas, Ber. Polarforsch., 212, 285-307, 1996.

Hald, M. and Vorren, T. O.: Modern and Holocene foraminifera and sediments on the continental shelf off Troms, North Norway, Boreas, 13, 133-154, 1984.

Hald, M., Steinsund, P. I., Dokken, T., Korsun, S., Polyak, L., and Aspeli, R.: Recent and late Quaternary distribution of Elphidium excavatum f. clavatum in the Arctic seas, Cushman Foundation Special Publications, 32, 141-153, 1994.

Hald, M., Andersson, C., Ebbesen, H., Jansen, E., KlitgaardKristensen, D., Risebrobakken, B., Salomonsen, G. R., Sarnthein, M., Sejrup, H. P., and Telford, R. J.: Variations in temperature and extent of Atlantic Water in the northern North Atlantic during the Holocene, Quaternary Sci. Rev., 26, 3423-3440, doi:10.1016/j.quascirev.2007.10.005, 2007.

Hald, M., Salomonsen, G. R., Husum, K., and Wilson, L. J.: A 2000 year record of Atlantic Water temperature variability from the Malangen Fjord, northeastern North Atlantic, The Holocene, 21, 1049-1059, doi:10.1177/0959683611400457, 2011.

Hass, H. C.: A method to reduce the influence of ice-rafted debris on a grain size record from northern Fram Strait, Arctic Ocean, Polar Research, 21, 299-306, doi:10.1111/j.17518369.2002.tb00084.x, 2002.

Hopkins, T. S.: The GIN Sea-A synthesis of its physical oceanography and literature review 1972-1985, Earth-Sci. Rev., 30, 175318, doi:10.1016/0012-8252(91)90001-v, 1991.

Husum, K. and Hald, M.: A continuous marine record 8000-1600 cal. yr BP from the Malangenfjord, north Norway: foraminiferal and isotopic evidence, The Holocene, 14, 877-887, 2004.

Ingvaldsen, R. B.: Width of the North Cape Current and location of the Polar Front in the western Barents Sea, Geophys. Res. Lett., 32, L16603, doi:10.1029/2005g1023440, 2005.
Ivanova, E. V., Ovsepyan, E. A., Risebrobakken, B., and Vetrov, A. A.: Downcore distribution of living calcareous foraminifera and stable isotopes in the western Barents Sea, The J. Foraminif. Res., 38, 337-356, 2008.

Jennings, A. E., Weiner, N. J., Helgadottir, G., and Andrews, J. T.: Modern foraminiferal faunas of the southwestern to northern Iceland shelf: oceanography and environmental controls, The J. Foraminif. Res., 34, 180-207, doi:10.2113/34.3.180, 2004.

Jernas, P., Klitgaard Kristensen, D., Husum, K., Wilson, L., and Koç, N.: Paleoenvironmental changes of the last two millennia on the western and northern Svalbard shelf, Boreas, 42, 236-255, 2013.

Juggings, S.: C2 Version 1.7.2 User Guide. Software for ecological and paleoecological data analysis and visualization, Newcastle University, Newcastle upon Tyne UK, 2010.

Klitgaard-Kristensen, D., Sejrup, H. P., and Haflidason, H.: The Last 18 kyr Fluctuations in Norwegian Sea Surface Conditions and Implications for the Magnitude of Climatic Change: Evidence from the North Sea, Paleoceanography, 16, 455-467, doi:10.1029/1999PA000495, 2001.

Klitgaard-Kristensen, D., Rasmussen, T. L., and Koç, N.: Palaeoceanographic changes in the northern Barents Sea during the last 16000 years - new constraints on the last deglaciation of the Svalbard-Barents Sea Ice Sheet, Boreas, 42, 798-813, doi:10.1111/j.1502-3885.2012.00307.x, 2013.

Knudsen, K. L.: Foraminiferer I Kvartær stratigrafi: Laboratorie og fremstillingsteknik samt udvalgte eksempler, Geologisk Tidsskrift 3, 1-25, 1998.

Lloyd, J. M.: Modern distribution of benthic foraminifera from Disko Bugt, West Greenland, The J. Foraminif. Res., 36, 315331, 2006.

Loeng, H.: Features of the physical oceanographic conditions of the Barents Sea, Polar Res., 10, 5-18, doi:10.1111/j.17518369.1991.tb00630.x, 1991.

Lubinski, D. J., Polyak, L., and Forman, S. L.: Freshwater and Atlantic water inflows to the deep northern Barents and Kara seas since ca $13{ }^{14} \mathrm{C}$ ka: foraminifera and stable isotopes, Quaternary Sci. Rev., 20, 1851-1879, doi:10.1016/S0277-3791(01)00016-6, 2001.

Mackensen, A. and Hald, M.: Cassidulina teretis Tappan and C. laevigata d'Orbigny; their modern and late Quaternary distribution in northern seas, The J. Foraminif. Res., 18, 16-24, doi:10.2113/gsjfr.18.1.16, 1988.

Mangerud, J. and Gulliksen, S.: Apparent radiocarbon ages of recent marine shells from Norway, Spitsbergen, and Arctic Canada, Quaternary Res., 5, 263-273, doi:10.1016/0033-5894(75)900289, 1975.

Mangerud, J., Bondevik, S., Gulliksen, S., Hufthammer, A. K., and Høisæter, T.: Marine ${ }^{14} \mathrm{C}$ reservoir ages for $19^{\text {th }}$ century whales and molluscs from the North Atlantic, Quaternary Sci. Rev., 25, 3228-3245, doi:10.1016/j.quascirev.2006.03.010, 2006.

Midttun, L.: Formation of dense bottom water in the Barents Sea, Deep Sea Res. Part A., 32, 1233-1241, 1985.

Polyak, L., Korsun, S., Febo, L. A., Stanovoy, V., Khusid, T., Hald, M., Paulsen, B. E., and Lubinski, D. J.: Benthic foraminiferal assemblages from the southern Kara Sea, a river-influenced arctic marine environment, The J. Foraminif. Res., 32, 252-273, doi:10.2113/32.3.252, 2002 . 
Poole, D.: Neogene and Quaternary Paleoenvironments in the Norwegian Sea Shelf, PhD Thesis, University of Troms $\emptyset$, Norway, 1994.

Rasmussen, T. L., Thomsen, E., Ślubowska, M. A., Jessen, S., Solheim, A., and Koç, N.: Paleoceanographic evolution of the SW Svalbard margin $\left(76^{\circ} \mathrm{N}\right)$ since $20000{ }^{14} \mathrm{C}$ yr BP, Quaternary Res., 67, 100-114, doi:10.1016/j.yqres.2006.07.002, 2007.

Rasmussen, T., Forwick, M., and Mackensen, A.: Reconstruction of Atlantic Water to Isfjorden, Svalbard during the Holocene: Correlation to climate and seasonality, Mar. Micropaleontol., 94-95, 80-90, 2012.

Rasmussen, T. L., Thomsen, E., Skirbekk, K., ŚlubowskaWoldengen, M., Klitgaard Kristensen, D., and Koç, N.: Holocene temperature variability in the northern Nordic Seas: Interplay of Atlantic-, Arctic- and Polar water masses, Quaternary Sci. Rev., doi:10.1016/j.quascirev.2013.10.034, 2013.

Reimer, P. J., Bard, E., Bayliss, A., Beck, J. W., Blackwell, P. G., Ramsey, C. B., Grootes, P. M., Guilderson, T. P., Haflidason,H., Hajdas, I., Hatté, C., Heaton, T. J., Hoffmann, D.L., Hogg, A. G., Hughen, K. A., Kaiser, K. F., Kromer, B., Manning, S. W., Niu, M., Reimer, R. W., Richards, D. A., Scott, E.M., Southon, Staff, R.A., J. R., Turney, C. S. M., and van der Plicht, J.: IntCal13 and Marine13 radiocarbon age calibration curves, 0-50,000 years cal BP, Radiocarbon, 55, 1869-1887, 2013.

Renssen, H., Seppä, H., Heiri, O., Roche, D. M., Goosse, H., and Fichefet, T.: The spatial and temporal complexity of the Holocene thermal maximum, Nat. Geosci., 2, 411-414, doi:10.1038/ngeo513, 2009.

Risebrobakken, B., Jansen, E., Andersson, C., Mjelde, E., and Hevrøy, K.: A high-resolution study of Holocene paleoclimatic and paleoceanographic changes in the Nordic Seas, Paleoceanography, 18, 1017, doi:10.1029/2002PA000764, 2003.

Risebrobakken, B., Moros, M., Ivanova, E. V., Chistyakova, N., and Rosenberg, R.: Climate and oceanographic variability in the SW Barents Sea during the Holocene, The Holocene, 20, 609-621, doi:10.1177/0959683609356586, 2010.

Risebrobakken, B., Dokken, T., Smedsrud, L., Andersson, C., Jansen, E., Moros, M., and Ivanova, E.: Early Holocene temperature variability in the Nordic Seas: The role of oceanic heat advection versus changes in orbital forcing, Paleoceanography, 26, PA4206, doi:10.1029/2011PA002117, 2011.

Rüther, D. C., Bjarnadóttir, L. R., Junttila, J., Husum, K., Rasmussen, T. L., Lucchi, R. G., and Andreassen, K.: Pattern and timing of the northwestern Barents Sea Ice Sheet deglaciation and indications of episodic Holocene deposition, Boreas, 41, 494-512, doi:10.1111/j.1502-3885.2011.00244.x, 2012.

Rytter, F., Knudsen, K. L., Seidenkrantz, M. S., and Eiríksson, J.: Modern distribution of benthic foraminifera on the north Icelandic shelf and slope, The J. Foraminif. Res., 32, 217-244, doi:10.2113/32.3.217, 2002.

Sætre, R.: The Norwegian coastal current: oceanography and climate, Tapir Academic Press, Trondheim, 2007.

Sarnthein, M., Van Kreveld, S., Erlenkeuser, H., Grootes, P. M., Kucera, M., Pflaumann, U., and Schulz, M.: Centennial-tomillennial-scale periodicities of Holocene climate and sediment injections off the western Barents shelf, $75^{\circ} \mathrm{N}$, Boreas, 32, 447461, doi:10.1111/j.1502-3885.2003.tb01227.x, 2003.
Seidenkrantz, M. S.: Cassidulina teretis Tappan and Cassidulina neoteretis new species (Foraminifera): stratigraphic markers for deep sea and outer shelf areas, J. Micropalaeontol., 14, 145-157, doi:10.1144/jm.14.2.145, 1995.

Sejrup, H. P., Birks, H. J. B., Klitgaard Kristensen, D., and Madsen, H.: Benthonic foraminiferal distributions and quantitative transfer functions for the northwest European continental margin, Mar. Micropaleontol., 53, 197-226, doi:10.1016/j.marmicro.2004.05.009, 2004.

Shackleton, N. J.: Attainment of isotopic equilibrium between ocean water and the benthonic foraminifera genus Uvigerina: Isotopic changes in the ocean during the last glacial, Centre National de la Recherche Scientifique Colleagues Internationeaux, 219, 203-209, 1974.

Simstich, J., Sarnthein, M., and Erlenkeuser, H.: Paired $\delta^{18} \mathrm{O}$ signals of Neogloboquadrina pachyderma (s) and Turborotalita quinqueloba show thermal stratification structure in Nordic Seas, Mar. Micropaleontol., 48, 107-125, 2003.

Skirbekk, K., Klitgaard Kristensen, D., Rasmussen, T. L., Koç, N., and Forwick, M.: Holocene climate variations at the entrance to a warm Arctic fjord: evidence from Kongsfjorden trough, Svalbard, in: Fjord Systems and Archives, edited by: Howe, J. A., Austin, W. E. N., Forwick, M., and Paetzel, M., Geological Society of London, Special Publications, 344, London, 289-304, 2010.

Ślubowska, M. A., Koç, N., Rasmussen, T. L., and KlitgaardKristensen, D.: Changes in the flow of Atlantic water into the Arctic Ocean since the last deglaciation: Evidence from the northern Svalbard continental margin, $80^{\circ} \mathrm{N}$, Paleoceanography, 20, PA4014, doi:10.1029/2005PA001141, 2005.

Ślubowska-Woldengen, M., Rasmussen, T. L., Koç, N., KlitgaardKristensen, D., Nilsen, F., and Solheim, A.: Advection of Atlantic Water to the western and northern Svalbard shelf since 17,500 cal yr BP, Quaternary Sci. Rev., 26, 463-478, doi:10.1016/j.quascirev.2006.09.009, 2007.

Stein, R. and Macdonald, R. W.: The organic carbon cycle in the Arctic Ocean, Springer, Berlin, 2004.

Steinsund, P. I.: Benthic foraminifera in surface sediments of the Barents and Kara Seas: Modern and late Quaternary applications, $\mathrm{PhD}$ thesis, University of Troms $\varnothing$, Norway, 1994.

Stuiver, M., Reimer, P. J., and Reimer, R. W.: CALIB 7.0. (WWW program and Documentation), 2005.

ter Braak, C. J. F. and Juggins, S.: Weighted averaging partial least squares regression (WA-PLS): an improved method for reconstructing environmental variables from species assemblages, Hydrobiologia, 269-270, 485-502, doi:10.1007/bf00028046, 1993.

Voronina, E., Polyak, L., De Vernal, A., and Peyron, O.: Holocene variations of sea-surface conditions in the southeastern Barents Sea, reconstructed from dinoflagellate cyst assemblages, J. Quaternary Sci., 16, 717-726, doi:10.1002/jqs.650, 2001.

Wilson, L. J., Hald, M., and Godtliebsen, F.: Foraminiferal faunal evidence of twentieth-century Barents Sea warming, Holocene, 21, 527-537, doi:10.1177/0959683610385718, 2011.

Wohlfarth, B., Lemdahl, G., Olsson, S., Persson, T., Snowball, I., Ising, J., and Jones, V.: Early Holocene environment on Bjørnøya (Svalbard) inferred from multidisciplinary lake sediment studies, Polar Res., 14, 253-275, 1995. 